\title{
SUCCESSION EDUCATION AND FAMILY-OWNED BUSINESSES IN SMALL AND MEDIUM-SCALE ENTERPRISES: AN EMPIRICAL REVIEW
}

\author{
Emmanuel E. Okoh ${ }^{1 \star}$, Rowland E. Worlu², Olabode A. Oyewunmi ${ }^{3}$, and Emmanuel T. \\ Emielu ${ }^{4}$ \\ ${ }^{1} \mathrm{Mr}$., okohee@gmail.com \\ ${ }^{2}$ Prof.,_rowland.worlu@covenantuniversity.edu.ng \\ 32Dr., olabode.oyewunmi@covenantuniversity.edu.ng \\ ${ }^{4} \mathrm{Mr}$., eemielu@gmail.com \\ Department of Business Management, College of Management and Social Sciences, Covenant \\ University, Ota, Ogun State, NIGERIA \\ ${ }^{*}$ Corresponding author
}

\begin{abstract}
Family-owned businesses (FOBs) play significant roles in the growth and development of economies across the globe. Extant literature has noted that clearly defined structures for leadership succession as well as wealth transfer are indispensable building blocks for the sustainable family business. However, a significant challenge facing family-owned enterprises in developing countries, particularly Nigeria, is lack of understanding of succession education as only about 20 percent have a plan for leadership succession and a tiny 3 per cent have a laid down strategy for wealth transfer. This study focuses on the review of extant studies on succession education of family-owned businesses (FOBs) in small and medium-scale enterprises (SMEs) in Nigeria. The research adopted a review of extant literature on succession education. The study found that succession education can form effective resilience to address the challenge of family business succession. Similarly, the paper recommends that the potential successors should be exposed to learning the business early to enable them to acquire adequate on-the-job training for a smooth transfer of ownership and entrepreneurship which is intended to enhance sustainability among Nigerian family-owned businesses.
\end{abstract}

Keywords: Family-owned Business; SMEs; Succession Education; Succession planning

\section{INTRODUCTION}

Family-owned businesses play important roles in the growth and development of economies across the globe. FOBs are the oldest and the most dominant form of businesses that create employment opportunities, facilitate competition, stimulate indigenous entrepreneurship, innovations and creativity, enhance foreign exchange revenues, and contribute to the gross domestic product (GDP) (Ogbechie \& Anetor, 2015). Extant literature has noted that clearly defined structures for leadership succession as well as wealth transfer are indispensable building blocks for the sustainable family business. Likewise, a significant challenge facing 
family-owned enterprises in Nigeria is poor, or lack of succession planning as only about 20 per cent have a plan for leadership succession, and a tiny 3 per cent have a laid down strategy for wealth transfer. This situation is responsible for the failures of many FOBs in Nigeria, particularly at the demise of the incumbent owners (Efferin \& Hartono, 2015).

In preparing the next generation to succeed in the family business, it is necessary to consider the role of education. There are two main kinds of education, namely: formal and informal (Wahjono \& Nirbito, 2014). Formal education implies the hierarchically structured coupled with the chronologically graded education system, running from primary school through the university (Olokundun, Ogbari, Obi, \& Ufua, 2019). However, informal education is defined as a continuous process whereby all individuals acquire attitudes, values, skills and knowledge from everyday experience and the educative influences and resources needed to influence and manipulate the business environments, in line with his set business goals and objectives. This could be achieved through an on-the-job training tradition and other specific goal-oriented training in family-owned businesses. Education dealing with family-owned business succession could be both formal and informal education and could also be categorised as succession education. In the context of this study, succession education is classified as any experience or education (formal or informal) that people acquire that facilitates their knowledge of succession.

The current research is focused on conducting an appraisal of previous studies on family-owned business succession via the critical review of extant literature. Thus, the purpose of this paper is to project knowledge on the subject of succession education among entrepreneurs and family-owned Small and Medium-scale Enterprises (SMEs).

\subsection{The Practice of Succession in Family-Owned Businesses}

Succession in a family-owned business is the process of transferring the ownership and management control of the entrepreneurial firm from the owner/founder to a successor (Theune, 2000). According to Osibanjo, Abiodun, and Obamiro (2011), Succession planning contributes significantly to the survival of an organisation. Succession planning involves a dynamic process that requires the incumbent owner to plan the company's future and then to execute the resulting plan (Adedayo, Ojo, \& Otsupius, 2016). It involves three steps, namely: identifying important needs, creating and evaluating candidates, and selecting the bestqualified candidate to occupy the key positions (Mokhber et al., 2017; Nnabuife \& Okoli, 2017). In a study on FOB in the Australian tourism sector, Getz and Carlsen (2000) observed thast it is vital for every FOB to develop a succession plan, and it should be appraised regularly. Getz and Carlsen also found that fewer businesses in the Australian tourism sector engage family members and dependants in the succession process. They argued that profitability motive is a critical factor for consideration in the succession planning process. Hence, the concept of succession in family-owned business practice can be defined as a conscious effort aimed to transfer either total or partial ownership or management of an established business from one generation to another generation.

Similarly, in a study on Canadian FOB practice, Lam (2009), highlighted individual competence as a core factor considered in the selection of successors. Lam added that family-owned business succession planning involved minimising conflicts and being able to differentiate the family and business systems. This narrative suggested that FOBs are different from one another, and this attribute makes it hard to have a universal theory for understanding succession (Ungerer \& Mienie, 2018).

In a study in Nigeria, Aderonke (2014) noted that the prevailing cultural practices determine the succession of family businesses. He observed incidences of conflict embedded in the succession process sometimes involves extended family system by the tradition of hereditary practices, which sometimes leads to a conflict of interests. He suggests the need for suitable succession plans to address the challenges that may arise due to cultural inclination and sustain the succession process. This observation supports the need for proper education that can create suitable awareness and inform better decisions in the succession planning process in Nigeria.

\subsection{Succession Education}

Findings from the extant literature reveal that several studies have been conducted in the sphere of family businesses about succession by various researchers. For instance, the studies by Tirdasari and Dhewanto (2012) on family-owned business succession in the hospitality business in Indonesia, and Obadan and Ohiorenoya (2013) on succession planning in small businesses in the hospitality industry in Benin City, Nigeria identified the role of competence of the potential successors in business succession planning. Interestingly, most of the scholars have raised the issue of succession education in their work but ignored 
the conceptualisation of the term "succession education".

Other studies reviewed such as Sajuyigbe, Oyedele and Unachukwu (2016) on succession planning and generational transition of FOBs in Nigeria, and Adedayo and Ojo (2016) on family conflict and sustainability of FOBs in Lagos and Ogun States, Nigeria all emphasised the involvement of potential successors in the running of the business and willingness to learn from each other as significantly contributing to the survival of family-owned enterprises after the exit of first-generation owners. However, the place of an intentional and deliberate engagement of succession education as a tool for facilitating business succession among familyowned businesses has been largely ignored by most studies reviewed on the subject matter.

Similarly, other robust studies such as Adom and Asare-Yeboa (2016) and Magasi (2016) all identified mentoring, entrepreneurial orientation, level of education/training, high level of business education coupled with relevant training and work experience and capability of the successor as important in determining the success and survival of the family-owned business. Again, the specific definition of succession education tailored towards smooth transition in the family business succession of SMEs is typically overlooked by most empirical studies reviewed on the subject matter.

From the foregoing, succession education involves knowledge and experience acquired through formal education and informal education sources such as on-the-job training and mentoring. Specifically, succession education can be regarded as any experience or education (formal or informal) that people acquire which facilitate their knowledge on succession.

\subsection{Empirical Review on FOBs, SMEs and Succession Education}

It seems arguable to state that successful FOBs practice that has no embedded succession plans for its next generation would likely fail to survive. Family-owned business succession involves the process of transitioning the ownership and management and ownership of the firm to the next generation of family members. Part of the process of transition sometimes includes family assets. Family members characteristically play a controlling role in both the management and ownership succession. Thus, the successful integration and management of the family component of the business will also have a determining effect on the success of the succession process (Ogbechie \& Anetor, 2015).

A previous study by Obadan and Ohiorenoya (2013) on succession planning in small businesses in the hospitality industry in Edo State, Nigeria have revealed that the competence of the potential successors is ignored in succession planning. Thus, no conscious efforts are made to empower the successors with the relevant succession education for a smooth succession process. Nevertheless, the situation is different from what is obtainable in Indonesia. According to Tirdasari and Dhewanto (2012) family restaurant business owners in Indonesia have a plan for their succession, even though such may not be written. They found that most of the businesses will persuade their children to join the business and send them to business school. Besides, the study revealed that all the respondents were aware of what they expected from their successors.

Likewise, Ogbechie and Anetor (2015) in their assessment of succession planning in FOBs in Lagos-Nigeria observed that the absence of a succession plan is not the significant factor responsible for succession problem although most family-owned businesses lack a succession plan. Besides, Sajuyigbe et al. (2016) identified succession planning and generational transition as the greatest challenges for FOBs in Nigeria. They argue that the involvement of potential successors in the running of the business and willingness to learn from each other will significantly contribute to the survival of family-owned enterprises after the exit of business founders. This narrative tends to point out that the successor to a business is saddled with the responsibility of making decisions that sustain the going concern of the business. It also suggested that effective succession planning, apart from equipping the successor with the requisite knowledge, would enhance the leadership appropriation skills needed to address emerging issues in the business process.

Adom and Asare-Yeboa (2016) evaluated human capital theory elements like education level, area of education, training and the influence of previous work experience on female entrepreneurship in subSaharan Africa, particularly Ghana. The findings revealed that education level, business training and knowledge acquired during their work contributed significantly to their success. Adom and Asare-Yeboa's findings were supported by Adedayo and Ojo (2017) study on family conflict and sustainability of FOBs in Lagos and Ogun States, Nigeria. Adedayo and Ojo opined that the successor should be brought into the family business early to gain the confidence and respect of other family and non-family employees. By coming into the business early, the successor will have the opportunity to undergo on-the-job training to acquire relevant skills and experience. 
The main argument of this research is that an increased level of succession education of SMEs owners will likely result in an increase in the level of succession initiative required for a transgenerational succession of FOBs. This is in alignment with the new trend of research on the subject of education and succession planning in FOBs practice (Magasi, 2016). Likewise, Magasi (2016) carried out a study in Tanzania and discovered that advancement in the level of education of entrepreneurs has a positive influence on preparing the successors. Similarly, Adom and Asare-Yeboa (2016), argued that an entrepreneur with an increased level of education in business studies together with relevant training and work experience, for example, is expected to outperform those who are bankrupt in these areas. Pan, Weng, Xu and Chan (2018) have also emphasized the importance of education in succession planning. They stressed that the successor must have an adequate level of education in the field of business and must have been working with the familyowned business for a good amount of time before the succession period. They also indicated the corporate philanthropy had been the strategy for most second-generation succession business to boost market and reputation despite the decline in performance.

Ogbechie and Anetor (2015) argued that culture and tradition are the other factors responsible for the problem of poor succession in family-owned businesses in Nigeria. The cultural practices are hinged on the male-primogeniture rule which believe that the founder's first son is usually the heir to the family business. Another study conducted in the United Kingdom by Liu, Eubanks and Chater (2015) observed that sampling bias, strong ties and nepotism in a family business makes the leadership believe that family members are better qualified than non-family members. This could lead to the failure of the family business succession.

\section{RESEARCH DESIGN}

This study adopted a review design and more specifically made use of an empirical review approach to analyse and gather inferences from existing literature that have addressed the subject of education and the success of succession planning. The study made use of conceptual literature of studies from science direct, Scopus and web of science across two decades (i.e. studies from the 2000s and studies from 2010s).

\section{DISCUSSION}

This research process provides a discussion about succession education and business succession in FOBs. Succession education refers to any experience or education (formal or informal) which people acquire that facilitates their knowledge on succession. The research key proposition is presented in this section.

Proposition: Succession education is an effective resilience to address the challenge of family business succession.

Succession education is considered an effective resilience to address the challenge of entrepreneurship business failure. The business world requires training, education and development that focus on issues irregular to firm characteristics governing by family ownership or control dormant (Ahmad \& Yaseen, 2018). Currently, attention has been focused on transmitting relevant information from incumbent to successor for suitable training and professional education of the successor. Thus, researchers are striving to develop educational tools which contribute to the transfer of information throughout the succession process Miller, Breton-Miller and Lester (2010), educational attainment builds up an individual's perceptions, unity, and harmony in FOBs. There is a correlation between the attainment of business education and the success of FOBs succession, and this enhances the chances of a successful succession transition (Ip \& Jacobs, 2006). A rigorous career development system needs to be developed to prepare the potential successor and this can enhance the competence of the successor by offering them any necessary education, training as well as by giving them periodic feedback on their performance within the family-owned business (Karim, 2014). Therefore, succession education is something that is critical to the survival of FOBs and contributes positively to smooth ownership succession (Wahjono \& Nirbito, 2014).

\subsection{Conclusion}

This study examined the effect of succession education on family-owned businesses succession in SMEs in Nigeria. The general conclusion is that level of education, on-the-job training and the willingness to learn have a strong impact on FOBs succession in the context of Nigeria. Specifically, this study revealed that succession education is any experience or education (formal or informal) that people acquire which facilitate their knowledge of succession.

\subsection{Managerial implications}

Family business owners need to promote succession education of their potential successors because, the 
higher the level of education of the incumbent and successors, the more likely the success of the succession process. Succession education will facilitate the establishment of diverse knowledge structures around the management hierarchies of the family-owned business as a prerequisite condition for accomplishing sustainable knowledge-based competitive advantage. Issues such as the fear of loss of control of ownership by the incumbent and unwillingness to allow the potential successor to come into the family business early can be addressed through succession education.

\subsection{Limitations and suggestions for future research}

Findings from this research may not be generalised but could be adaptable to other contexts because the research was based on the empirical review. It is recommended that further research be conducted on education, succession planning and implementation from a quantitative perspective. .

\section{ACKNOWLEDGEMENT}

The authors appreciate the immense support received from Covenant University Centre for Research, Innovation and Discovery (CUCRID) during the preparation of this paper for a conference presentation.

\section{REFERENCE LIST}

Adedayo, O., \& Ojo, O. (2017). Family owned business (FOB) succession and sustainability: Evaluation of some selected theories applicable to FOB succession research in Nigeria. Prudent Research Journal of Business Management and Economics, 1(1), 1-11. Retrieved from http://www.prudentjournals.org/PRJBME

Adedayo, O. S., Ojo, J. O., \& Otsupius, A. I. (2016). Planning for succession and firm's sustainability: Evidence from family owned businesses in Lagos and Ogun States, Nigeria. Issues in Business Management and Economics, 4(6), 63-69. https://doi.org/10.15739/IBME.16.009

Adom, K., \& Asare-Yeboa, I. T. (2016). An evaluation of human capital theory and female entrepreneurship in sub-Sahara Africa: Some evidence from Ghana. International Journal of Gender and Entrepreneurship, 8(4), 402-423. https://doi.org/10.1108/JJGE-12-2015-0048

Ahmad, Z., \& Yaseen, M. R. (2018). Moderating role of education on succession process in small family businesses in Pakistan. Journal of Family Business Management, 8(3), 293-305. https://doi.org/10.1108/JFBM-12-2017-0041

Ip, B., \& Jacobs, G. (2006). Business succession planning: A review of the evidence. Journal of Small Business and Enterprise Development, 13(3), 326-350. https://doi.org/10.1108/14626000610680235

Karim, T. (2014). Succession Management and its impact on Family Business. 6(37), 315-321.

Magasi, C. (2016). Factors influencing business succession planning among SMEs in Tanzania. European Journal of Business and Management, 8(3), 2222-2839. Retrieved from https://www.researchgate.net/publication/305710018

Mokhber, M., Gi Gi, T., Abdul Rasid, S. Z., Vakilbashi, A., Mohd Zamil, N., \& Woon Seng, Y. (2017). Succession planning and family business performance in SMEs. Journal of Management Development, 36(3), 330-347. https://doi.org/10.1108/JMD-12-2015-0171

Nnabuife, E., \& Okoli, I. E. (2017). Succession planning and sustainability of selected family owned businesses in Anambra State, Nigeria. European Journal of Business and Management, 9(34), 155167.

Obadan, J. A., \& Ohiorenoya, J. O. (2013). Succession Planning in Small Business Enterprises in Edo State of Nigeria. European Scientific Journal ', 9(31), 64-77.

Ogbechie, R., \& Anetor, O. F. (2015). An appraisal of succession planning in family-owned businesses in Lagos State, Nigeria. In European Journal of Business and Management www.iiste.org ISSN (Vol. 7). Retrieved from Online website: www.iiste.org

Olokundun, M. A., Ogbari, M. E., Obi, J. N., \& Ufua, D. E. (2019). Business incubation and student idea validation: A focus on Nigerian universities. In Journal of Entrepreneurship Education (Vol. 22). 
Osibanjo, A., Abiodun, A., \& Obamiro, K. (2011). Succession planning and organizational survival: Empirical study on Nigerian private tertiary institutions. Serbian Journal of Management, 6(2), 231-246. https://doi.org/10.5937/sjm1102231a

Sajuyigbe, A. S., Oyedele, O., \& Unachukwu, J. C. (2016). Succession Planning and Generational Transition: The Greatest Challenges for Family-owned Businesses. 3RD INTERNATIONAL CONFERENCE ON ENTREPRENEURSHIP AND ENTREPRENEURSHIP EDUCATION. https://doi.org/10.5171/2012.421949

Tirdasari, N. L., \& Dhewanto, W. (2012). Family Business Succession in Indonesia: A Study of Hospitality Industry. Procedia - Social and Behavioral Sciences, 57, 69-74. https://doi.org/10.1016/j.sbspro.2012.09.1159

Ungerer, M., \& Mienie, C. (2018). A family business success map to enhance the sustainability of a multigenerational family business. International Journal of Family Business and Management Studies, 2(1), 1-13. https://doi.org/10.15226/2577-7815/2/1/00112

Wahjono, S. I., \& Nirbito, J. G. (2014). SUCCESSION PLANNING AS AN ECONOMIC EDUCATION TO IMPROVE FAMILY BUSINESS PERFORMANCE IN EAST JAVA PROVINCE OF INDONESIA Contribution/ Originality. Journal of Asian Scientific Research, 4(411), 649-663. Retrieved from http://www.aessweb.com/journals/5003 